\title{
Survey of Chilli Leaf Curl Complex Disease in Eastern Part of Uttar Pradesh
}

\author{
AN Chaubey and RS Mishra* \\ Department of Plant Pathology, ND University of Agriculture \& Technology, India
}

Received: December 04, 2017; Published: December 13, 2017

*Corresponding author: RS Mishra, Department of Plant Pathology, ND University of Agriculture \& Technology, Kumarganj, Faizabad-224229, UP, India

\begin{abstract}
Chili (Capsicum annuum L.) is an economically important and widely cultivated crop of India. Chilli leaf curl virus is one of the major limiting factors in chili production, which decreases yield significantly. The experiment was carried out in one hundred fifty villages randomly selected in eastern Uttar Pradesh viz, Sultanpur and Faizabad districts during 2014 and 2015 from March to May each year. The highest leaf curl incidence was noticed in Sewra (67.39 \%) followed by Hasuimukundpur (65.22\%) and Etwara (64.07\%) in 2014, whereas in 2015, it was found maximum in Sewra (61.44\%), Hasuimukundpur (59.79\%) and Isawli (57.07\%). In case of block wise, the maximum incidence was found Amaniganj (59.53, 50.79\%) and Kurwar (54.70, 52.91\%) in 2014 and 2015 respectively. While the lowest incidence was observed at Milkipur $47.46 \%$ in 2014 and $41.48 \%$ in 2015 the average leaf curl disease incidence was recorded highest in 2014 at both districts.
\end{abstract}

Keywords: Survey; Chilli leaf curl; Eastern Uttar Pradesh

\section{Introduction}

Chilli (Capsicum annuum $\mathrm{L}$ ) is one of the most valuable cash crops of India. It is a common and widely cultivated spices crop almost all over the world. Chilli is a richest source of vitamin $\mathrm{C}$ and A Howard [1].The chilly fruits are small in size and known for their sharp acidic flavor and colour. At present, chilly is produced in India about 1260.1thousands metric ton from an area of 792.1 thousands hectare, Anonymous [2]. Andhra Pradesh is the largest producing state of chilly. Indian chillies are mostly exported to Sri Lanka, USA, Nepal, Mexico, Malaysia and Bangladesh. Chilli suffers from a large number of viral, fungal, bacterial, nematode and phytoplasma diseases. Viruses is known to cause different symptoms like mosaic, ring spot, curling, yellowing etc. on chilly and these symptoms result heavy economic losses of about 15billion US Dollar per annum worldwide Van Fanbing [3].

Among them, chilly leaf curl is very common and affected to entire plants in the field with variable symptoms. It has been observed to cause high disease incidence with showing the symptoms of leaf curling, puckering and reduced size of leaves, closely set internodes and dwarfing of plants. These symptoms produce witch broom appearance and causes to failure of fruits setting. The fruit sets usually small and deformed. However, there are no published reports on the distribution of leaf curl viral diseases in major chilly growing areas of eastern Uttar Pradesh viz; Faizabad and sultanpur districts although, it is important disease of chilly crop.

\section{Materials and Methods}

The design adopted for the survey was stratified multistage sampling in two districts namely Faizabad and Sultanpur. The districts were classified into three blocks based on number of village surveyed. The survey was confined to five village of each block and villages were selected at random. These survey villages were visited for two consecutive years 2014 and 2015 from planting stage to harvesting stage i.e. $3^{\text {rd }}$ week of March, April and May. Data on the total number of plants, number of virus infected plants in per square meter. The days after disease appearance and visual disease incidence scoring method was adopted 0-9 point scale, Percentage of disease incidence was obtained by standard methods Joshi and Chaudhry [4] Other viral disease symptoms on chilly plant in the surveyed area were seen and collected separately for further confirmation through visual observation with consultation of standard literature McRae et al. [5-7] Per cent disease incidence was calculated given by Joshi and Chaudhry (1981) [4] as under:

$$
\text { Disease incidence }(\%)=\frac{\text { Number of infected plants per plots }}{\text { Number of plants (diseased }+ \text { healthy) per plots }} \times 100
$$

\section{Results and Discussion}

Field survey were conducted from 2014 and 2015 in 30 villages and total 150 fields in major chilly growing area of Faizabad and Sultanpur districts of eastern Uttar Pradesh. The results of survey revealed that most of the fields were found more than one viral infected symptoms. The virus infected leaf sample were collected 
and visual identified as leaf curl, mosaic mottle, puckering, yellowing, leaf rolling and distortion mosaic with the standard literature cited by Paul et al. [8], Puttarudriah [9] and Muniyappa [10]. The infection of chilly leaf curl virus was found in almost all fields with 36.86 to $67.70 \%$ in 2014 and 25.53 to $67.39 \%$ average disease intensity in 2015. The highest leaf curl incidence was noticed in Sewra (67.39\%) followed by Hasuimukundpur (65.22\%) and Etwara (64.07\%) in 2014, whereas in 2015, it was highest in Sewra (61.44\%), Hasuimukundpur (59.79\%) and Isawli (57.07\%).

The lowest leaf curl incidence was noticed in Ahran (25.53$30.30 \%)$ Sholapur (36.83\%-36.04\%) and Isawlibhari (37.33\%$31.89 \%$ ) in 2014 and 2015, respectively (Table 1) When the leaf curl disease incidence data was analyzed at block wise. The maximum incidence was found 59.53, 50.79\% at Amaniganj and
54.70, 52.91\% at Kurwar in 2014 and 2015, respectively. While the least incidence was observed at Milkipur $47.46 \%$ in 2014 and $41.48 \%$ in 2015 (Table 2) The average leaf curl disease incidence was observed highest in 2014 at both districts viz., Sultanpur (54.76\%) and Faizabad (51.72\%) due to favorable environmental condition was found for the growth of white fly, which is a key vector for the transmission virus. The similar finding was reported by Gupta et al. [11] and Meena et al. [12] The leaf curl disease incidence was recorded lowest in March and highest in May at both the year because of less inoculums were persist in the field during the March, when plants are in growing phase but inoculums were consequently perpetuate due to build up of white fly population during April and May and transmit to another Plants for its infection. The observations have been supported by Iqbal et al. [13] and Navot et al. [14] (Table 3).

Table 1: Survey of chilli leaf curl disease incidence during the growing period of 2014 and 2015 in different villages of eastern UP.

\begin{tabular}{|c|c|c|c|c|c|c|c|c|c|c|c|c|}
\hline \multirow[b]{3}{*}{$\begin{array}{c}\text { S. } \\
\text { No }\end{array}$} & \multirow[b]{3}{*}{ Districts } & \multirow[b]{3}{*}{ Blocks } & \multirow[b]{3}{*}{ Villages } & \multirow{3}{*}{$\begin{array}{c}\text { No. of } \\
\text { field } \\
\text { surveyed }\end{array}$} & \multicolumn{8}{|c|}{ Per cent disease incidence of chilly leaf curl diseases } \\
\hline & & & & & \multicolumn{4}{|c|}{2014} & \multicolumn{4}{|c|}{2015} \\
\hline & & & & & $\begin{array}{c}3^{\text {rd }} \\
\text { week } \\
\text { of } \\
\text { March }\end{array}$ & $\begin{array}{c}3^{\text {rd }} \\
\text { week } \\
\text { of April }\end{array}$ & $\begin{array}{c}3^{\text {rd }} \\
\text { week } \\
\text { of May }\end{array}$ & Average & $\begin{array}{c}3^{\text {rd }} \\
\text { week } \\
\text { of } \\
\text { March }\end{array}$ & $\begin{array}{c}3^{\text {rd }} \\
\text { week } \\
\text { of } \\
\text { April }\end{array}$ & $\begin{array}{c}3^{\text {rd }} \\
\text { week } \\
\text { of May }\end{array}$ & Average \\
\hline \multirow{15}{*}{1} & \multirow{15}{*}{ Sultanpur } & \multirow{5}{*}{ Dhanpatganj } & Sewra & 5 & 28.83 & 78.63 & 64.70 & 67.39 & 26.53 & 72.56 & 85.23 & 61.44 \\
\hline & & & Baraitpara & 5 & 20.85 & 65.63 & 84.89 & 57.12 & 15.75 & 45.46 & 63.75 & 41.65 \\
\hline & & & Etwara & 5 & 27.98 & 72.37 & 91.87 & 64.07 & 22.76 & 52.25 & 69.56 & 48.16 \\
\hline & & & Shohagpur & 5 & 10.50 & 46.37 & 53.70 & 36.86 & 12.56 & 44.23 & 51.33 & 36.04 \\
\hline & & & Pipari & 5 & 24.58 & 70.67 & 89.58 & 61.61 & 18.76 & 49.36 & 67.56 & 45.23 \\
\hline & & \multirow{5}{*}{ BaldiRai } & Hausimukundpur & 5 & 27.21 & 74.58 & 93.87 & 65.22 & 25.46 & 64.36 & 89.56 & 59.79 \\
\hline & & & Rancha & 5 & 18.43 & 62.68 & 73.74 & 51.62 & 16.96 & 46.37 & 77.53 & 46.95 \\
\hline & & & Deeh & 5 & 15.86 & 49.73 & 61.53 & 42.37 & 13.23 & 39.37 & 58.56 & 37.05 \\
\hline & & & Megmau & 5 & 19.47 & 63.46 & 77.34 & 53.42 & 17.56 & 47.36 & 79.36 & 48.09 \\
\hline & & & Behi & 5 & 17.33 & 58.37 & 68.87 & 48.19 & 16.57 & 44.38 & 75.48 & 45.48 \\
\hline & & \multirow{5}{*}{ Kurwar } & Brasin & 5 & 21.47 & 68.67 & 87.34 & 59.16 & 19.75 & 59.56 & 81.56 & 53.62 \\
\hline & & & Shadipur & 5 & 20.73 & 66.64 & 83.98 & 57.12 & 18.38 & 53.38 & 79.88 & 50.55 \\
\hline & & & Sarayamaphi & 5 & 18.63 & 61.98 & 73.88 & 51.50 & 17.56 & 49.63 & 72.34 & 46.51 \\
\hline & & & Isrwali & 5 & 24.78 & 71.84 & 90.37 & 62.33 & 23.58 & 69.78 & 80.56 & 57.97 \\
\hline & & & Walipur & 5 & 21.86 & 20.73 & 87.67 & 43.42 & 20.56 & 67.43 & 79.67 & 55.89 \\
\hline \multirow{15}{*}{2} & \multirow{15}{*}{ Faizabad } & \multirow{5}{*}{ Milkipur } & Jorium & 5 & 15.73 & 48.89 & 62.37 & 42.33 & 14.38 & 45.87 & 59.46 & 39.90 \\
\hline & & & Sidhwana & 5 & 18.86 & 61.88 & 73.46 & 51.40 & 16.76 & 47.21 & 69.13 & 44.37 \\
\hline & & & Tendha & 5 & 20.33 & 67.21 & 84.67 & 57.40 & 19.44 & 52.43 & 73.48 & 48.45 \\
\hline & & & Iswalibhari & 5 & 13.44 & 47.43 & 51.13 & 37.33 & 11.75 & 34.37 & 49.56 & 31.89 \\
\hline & & & Bawa & 5 & 17.75 & 59.24 & 69.48 & 48.82 & 16.38 & 44.56 & 67.36 & 42.77 \\
\hline & & \multirow{5}{*}{ Amaniganj } & Pithla & 5 & 22.74 & 67.58 & 87.58 & 59.30 & 20.56 & 56.67 & 78.76 & 52.00 \\
\hline & & & Etwaja & 5 & 19.46 & 64.34 & 78.21 & 54.00 & 16.56 & 45.37 & 67.25 & 43.06 \\
\hline & & & Barawalijham & 5 & 24.77 & 72.25 & 91.68 & 62.90 & 21.73 & 5823 & 81.56 & 53.84 \\
\hline & & & Akma & 5 & 25.67 & 73.24 & 92.33 & 63.75 & 22.75 & 61.37 & 84.37 & 56.16 \\
\hline & & & Amwachetan & 5 & 20.86 & 66.43 & 85.87 & 57.72 & 23.37 & 65.86 & 87.43 & 58.89 \\
\hline & & \multirow{5}{*}{ Haringtanganj } & Bharypur & 5 & 15.73 & 48.68 & 60.84 & 41.75 & 17.47 & 46.57 & 68.38 & 44.14 \\
\hline & & & Ahran & 5 & 12.47 & 43.88 & 50.24 & 25.53 & 8.56 & 32.76 & 49.57 & 30.30 \\
\hline & & & Bhetari & 5 & 17.77 & 60.10 & 71.63 & 49.83 & 14.56 & 39.38 & 57.67 & 37.20 \\
\hline & & & Hardoiya & 5 & 21.56 & 69.24 & 88.48 & 59.76 & 18.76 & 47.34 & 73.48 & 46.53 \\
\hline & & & Ghatampur & 5 & 19.74 & 64.24 & 77.88 & 53.95 & 20.57 & 51.62 & 78.84 & 50.34 \\
\hline
\end{tabular}


Table 2: Incidence of chilly leaf curl virus in various block of Sultanpur and Faizabad districts during 2014 and 2015.

\begin{tabular}{|c|c|c|c|c|c|c|c|c|c|}
\hline \multirow{3}{*}{ S. No. } & \multirow{3}{*}{ Blocks } & \multicolumn{8}{|c|}{ Per cent disease Incidence } \\
\hline & & \multicolumn{4}{|c|}{2014} & \multicolumn{4}{|c|}{2015} \\
\hline & & $\begin{array}{l}3^{\text {rd }} \text { week of } \\
\text { March }\end{array}$ & $\begin{array}{l}3^{\text {rd }} \text { week of } \\
\text { April }\end{array}$ & $\begin{array}{c}3^{\text {rd }} \text { week of } \\
\text { May }\end{array}$ & Average & $\begin{array}{l}3^{\text {rd }} \text { week of } \\
\text { March }\end{array}$ & $\begin{array}{c}3^{\text {rd }} \text { week of } \\
\text { April }\end{array}$ & $\begin{array}{c}3^{\text {rd }} \text { week of } \\
\text { May }\end{array}$ & Average \\
\hline 1 & Dhanpatganj & 22.55 & 66.73 & 82.95 & 57.41 & 19.27 & 52.77 & 67.49 & 46.51 \\
\hline 2 & Baldi Rai & 19.66 & 61.67 & 75.07 & 52.16 & 17.96 & 48.37 & 76.10 & 47.48 \\
\hline 3 & Kurwar & 21.49 & 57.97 & 84.65 & 54.70 & 19.97 & 59.96 & 78.80 & 52.91 \\
\hline 4 & Milkipur & 17.22 & 56.93 & 68.22 & 47.46 & 15.74 & 44.89 & 63.80 & 41.48 \\
\hline 5 & Amaniganj & 22.70 & 68.77 & 87.13 & 59.53 & 20.99 & 57.50 & 73.87 & 50.79 \\
\hline 6 & Haringtanganj & 17.45 & 57.23 & 69.81 & 48.17 & 15.98 & 43.54 & 6559 & 41.70 \\
\hline
\end{tabular}

Table 3: Incidence of chilli leaf curl virus at district level during the different growing periods of 2014-2015.

\begin{tabular}{|c|c|c|c|c|c|c|c|c|c|}
\hline \multirow{3}{*}{ S. No. } & \multirow{3}{*}{ Years } & \multicolumn{8}{|c|}{ Per cent disease Incidence } \\
\hline & & \multicolumn{4}{|c|}{ Sultanpur } & \multicolumn{4}{|c|}{ Faizabad } \\
\hline & & $\begin{array}{c}3^{\text {rd }} \text { week of } \\
\text { March }\end{array}$ & $\begin{array}{c}3^{\text {rd }} \text { week of } \\
\text { April }\end{array}$ & $\begin{array}{c}3^{\text {rd }} \text { week of } \\
\text { May }\end{array}$ & Average & $\begin{array}{c}3^{\text {rd }} \text { week of } \\
\text { March }\end{array}$ & $\begin{array}{c}3^{\text {rd }} \text { week of } \\
\text { April }\end{array}$ & $\begin{array}{c}3^{\text {rd }} \text { week of } \\
\text { May }\end{array}$ & Average \\
\hline 1 & 2014 & 21.23 & 62.12 & 80.89 & 54.76 & 19.12 & 60.98 & 75.05 & 51.72 \\
\hline 2 & 2015 & 19.07 & 53.70 & 74.13 & 48.97 & 17.57 & 48.64 & 67.57 & 44.66 \\
\hline
\end{tabular}

During the survey, different types of viral symptoms were observed in all blocks, the natural of symptoms on chilly plants were collected and grouped. The grouped symptoms were identified and calculated per cent disease severity separately. The symptoms of the viral infected chilly plants were found clearing of veins of the apical leaves, followed by dark green to light green mottling, mild to severe mosaic, necrotic streaks on the vein and petiole with stunted and bushy appearance were identified as necrotic leaves Talukdar et al. [15]. The less number of branches with reduced length of root was considered as mottle virus Yadav et al. [16]. Wavy midrib, upward curling, reduced leaf area with vein clearing and banding was grouped in mosaic mottling. The characteristic field symptoms were considered for leaf curl is upward curling; puckering and reduced size of leaves with severely affected plants was stunted and produced no fruit Senanayake $[17,18]$ The viral severity was estimated based on the number of plants found characteristics symptoms of each virus (Table 4). Infection of leaf curling was found severe in all blocks. Whereas as mosaic mottling virus was severe in Dhanpatganj and leaf rolling was in Baldirai. Other disease symptoms were recorded moderate to mild infection

Table 4: Types of viral symptoms in different blocks of eastern Uttar Pradesh during crop periods of 2014 and 2015.

\begin{tabular}{|c|c|c|}
\hline S. No. & Blocks & Symptoms \\
\hline 1 & Dhanpatganj & Leaf curling**, Leaf rolling**, Mosaic, Necrosis of leaves*, Distortion mosaic and mosaic mottling*** \\
\hline 2 & Baldi Rai & Leaf curling***, Leaf rolling**, Mosaic, Necrosis of leaves**, Distortion mosaic* and mosaic mottling* \\
\hline 3 & Kurwar & Leaf curling**, Leaf rolling**, Mosaic, Necrosis of leaves**, Distortion mosaic* and mosaic mottling* \\
\hline 4 & Milkipur & Leaf curling**, Necrosis of leaves** and Mosaic* $^{*}$ \\
\hline 5 & Amaniganj & Leaf curling***, Mosaic ${ }^{* *}$, Leaf rolling, Necrosis of leaves ${ }^{* *}$ and Mosaic mottling** \\
\hline 6 & Haringtanganj & Leaf curling**, Mosaic mottling* and Necrosis of leaves ${ }^{* *}$ \\
\hline
\end{tabular}

***Severe incidence, ${ }^{* *}$ Moderate Incidence and *Mild Incidence.

\section{Conclusion}

An overall survey revealed that chilly leaf curl virus was found all surveyed field in continuous growing period. It is due to growing of susceptible local cultivars prevailing in the districts as for multiplication and spread of virus.

\section{References}

1. Anonymous (2012) Area and production of vegetable crops, 2011-12. National Horticulture Board pp. 29.

2. DM JB Senanayake, B Mandal, S Lodha, A Varma (2007) First report of Chilli leaf curl virus affecting chilli in India. Plant Pathology 56: 343.

3. Harsh Deep Yadav, Poonam Yadav, Lokendra Yadav, Prabhat Kumar Yadav (2013) Efficacy of chilli mottle virus disease on root constraints of Capsicum annuum L at Agra, India. World J of Applied Sci and Res p. 57-59.

4. Howard LR, Talcott ST, Brenes CH, Villalon B (2000) Changes on Phytochemical antioxidant activity of selected pepper cultivars (Capsicum Species) as influenced by maturity. Journal of Agricultural Food chemistry 48(5): 1713-1720.

5. Hussan MA (1932) Leaf curls in cotton and other plants. Nature, London, 103: 312 .

6. J Talukdar, AK Saikiaand, P Borah (2015) Survey and detection of the diseases of Bhut Jolokia (Capsicum chinense Jacq.) in Assam. Journal Crop and Weed 11: 186-192.

7. Rishikesh Meena, Vidya Panti, DK Arora (2006) an epidemic of chilli leaf curl disease in Rajasthan. J Phytol Res 19(2): 335-336. 
8. Jha A, Rayachaudhury SP (1956) Mosaic disease of chilli (Capsicum frutescens. L) Indian. J Agric Sci 26: 217-222.

9. Joshi GC, Choudhary B (1981) Screening of Lycoprersicon and Solanum species for resistance to leaf curl virus. Veg Sci 8: 45-50.

10. McRae W (1924) Economic Botany part III, Mycology. Annual Reporter Board Scientific Advice India p. 31-35

11. MIL Brath, CM and Cook AA (1971) Virus diseases of pepper (Capsicum Spp) in Hawaii. Plant Dis Rep 55: 783-785.

12. Muniyappa V (1980) Whiteflies In: Vector of Plant Pathogens, Ed KF Harris and K Marmorosch (Eds.). Academic press, New York, USA, p. 3985.

13. Puttarudraiah M (1959) Short review on the chilli leaf curl complex and spray programme for its control. Mysore Agric J 34(2): 93-95.

14. VK Gupta, Rakesh Sharma, Satnam Singh, Jawala Jindal, VK Dilawari (2010) Efficiency of Bemisia tabaci (Gennadius) populations from different plant host for acquisition and transmission of cotton leaf curl virus. Indian journal of Biotechnology 9: 271-275.

15. Navot N, Pichersky E, Zeidan M, Zamir D, Czosnek H (1991) Tomato yellow leaf curl virus: a whitefly transmitted geminivirus with a single genomic component. Virology 185(1): 151-161.

16. Paul WR, Fernando M (1939) Effect of manuring on incidence of chilli leaf curl. Trop Agriculturist 109(4): 251-259.

17. Shomaila Iqbal, Muhammad Ashfaq, Hussain Shah, M Inam-Ul-Haq, AzizUd- Din (2012) Prevalence and distribution of cucumber mosaic virus (cmv) in major chilli growing areas of Pakistan. Pak J Bot 44(5): 17491754.

18. Van Fanbing L (1999) Monoclonal and recombinant antibodies of potyviral proteins and their application, Virology, Stuttgart University, Germany. 185: 151-161.

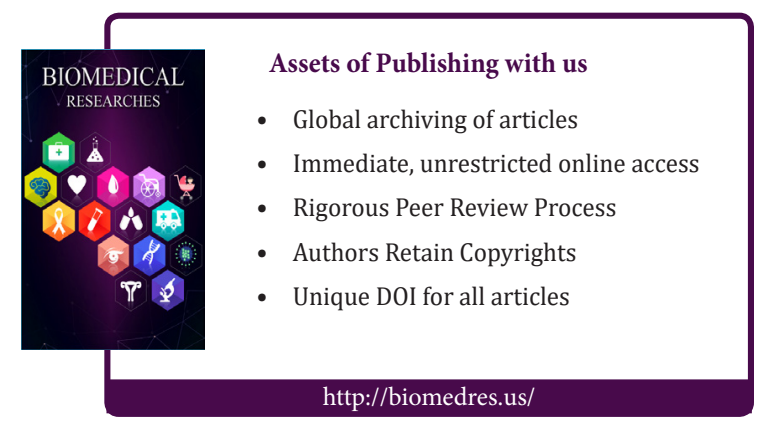

